ably occurred with height and weight growth, requires an increase in the body's protein content. The body's protein content in turn will increase if the net protein synthesis (S-B) is positive. Since protein synthesis is an energy expensive process (8), while protein breakdown is not, the enhancement of net protein synthesis by a reduction of protein breakdown relative to protein synthesis is clearly an energy efficient adaptation permitting increased growth at a minimal energy expenditure.

Acknowledgments. The authors thank Miss Anne Dumas, Therapeutic Dietitian, The Montreal Children's Hospital, for her help with the dietary aspects of this study and Dr. Margaret Wood for her help with the statistical aspects of the study.

\section{REFERENCES}

1. Pencharz PB 1983 Energy intakes and low fat diets in children with cystic fibrosis. J Pediatr Gastoenterol Nutr 2:400-402

2. Lapey A, Kattwinkel J, di Sant'Agnese PA, Laster E 1974 Steatorrhea and azotorrhea and their relation to growth and nutrition in adolescents and young adults with cystic fibrosis. J Pediatr 84:328-334

3. Parsons HG, Beaudry P, Dumas A, Pencharz PB 1983 Energy needs and growth in children with cystic fibrosis. J Pediatr Gastroenterol Nutr 2:44-49

4. Tanner JM, Whitehouse RH, Takaishi M 1966 Standards from birth to maturity for height, weight, height velocity and weight velocity: British children, 1965. Part II. Arch Dis Childh 41:613-635

5. Bell L, Hatcher J, Chan L, Fraser D 1979 Development of a computerized system for calculating nutrient intakes. J Can Diet Assoc 40:30-36

6. Munro HN, Fleck A 1969 Analysis of tissues and body fluids for nitrogenous constituents. In: Munro HN (ed) Mammalian Protein Metabolism, Vol fll. Academic Press, New York, pp 423-525
7. Picou D, Taylor-Roberts T 1969 The measurement of total body protein synthesis and catabolism and nitrogen turnover in infants in different nutritional status and receiving different amounts of dietary protein. Clin Sci 36:283-296

8. Pencharz PB, Parsons HG, Motil KJ, Duffy BJ 1981 Total body protein turnover and growth in children: is it a futile cycle? Med Hypoth 7:155-160

9. Steffee WP, Goldsmith RS, Pencharz PB, Scrimshaw NS, Young VR 1976 Dietary protein intake in the dynamic aspects of whole body protein metabolism in adult humans. Metabolism 25:281-297

10. Pencharz PB, Steffee WP, Cochran W, Scrimshaw NS, Rand WM, Young VR 1977 Protein metabolism in human neonates. Clin Soc Mol Med 52:485498

11. Pencharz PB, Masson M, Desgranges F, Papageorgious A 1981 Total body protein turnover in human premature neonates: effects of birthweight, intrauterine nutritional status and diet. Clin Sci 61:207-215

12. Duffy B, Gunn T, Collinge J, Pencharz PB 1981 The effect of varying protein quality and energy intake on the nitrogen metabolism of parenterally fed very low birthweight $(<1600 \mathrm{~g})$ infants. Pediatr Res 15:1040-1044

13. Parsons HG, Wood MM, Pencharz PB 1983 Diurnal variation in urine ${ }^{15} \mathrm{~N}$ urea content, estimates of whole body protein turnover, and isotope recycling in healthy meal-fed children with cystic fibrosis. Can J Physiol Pharmacol 61:72-80

14. Siegal S 1956 Non-parametric Statistics for Behavioural Sciences. McGrawHill, Toronto

15. Pencharz PB, Motil KJ, Parsons HG, Duffy BJ 1980 The effect of an energy restricted diet on the protein metabolism of obese adolescents: nitrogen balance and whole body protein turnover. Clin Sci 59:13-18

16. Kien CL, Young VR, Rohrbaugh DK, Burke JM 1978 Whole body protein synthesis and breakdown rates in children before and after reconstructive surgery of the skin. Metabolism 27:27-34

17. Adenyi-Jones SJ, Suskind R, Polombo J, Pena Cruz V, Kaw KT 1979 Growth at puberty: possible mechanism of increased growth from protein turnover and energy balance studies. Pediatr Res 13:326 (abstr)

18. Waterlow JC, Golden MHN, Garlick PJ 1978 Protein turnover in man measured with ${ }^{15} \mathrm{~N}$ : comparison of end-product and dose regimes. Am J Physiol 235:E165-E174

\title{
A Differential Effect of Thyroxine and Glucocorticoids on Fetal Brain and Heart Insulin Receptor
}

\author{
SHERIN U. DEVASKAR, PAUL F. GRIM III, AND UDAY P. DEVASKAR \\ Division of Perinatal-Neonatal Medicine, Department of Pediatrics, Saint Louis University School of Medicine, \\ Pediatric Research Institute, Cardinal Glennon Memorial Hospital for Children, St. Louis, Missouri 63104
}

\begin{abstract}
We investigated the effect of thyroxine (T4), glucocorticoids, and T4 + glucocorticoids on the maturation of fetal rabbit brain and heart insulin receptors. Five doses of $\mathrm{T} 4$ over 10 days $(50 \mu \mathrm{g} / \mathrm{kg}$ body weight per dose) were administered to the mother; significant amounts crossed the placenta (fetal serum free $\mathrm{T} 4=0.75 \pm 0.08$ versus a control of $0.21 \pm 0.02 \mathrm{ng} / \mathrm{dl}, p<0.02$ ) and increased the specific binding of $\left[{ }^{125} I\right]$ insulin to 30 -day-old fetal heart membranes from a control of $3.6 \pm 0.74 \%$ per $100 \mu \mathrm{g}$ protein to $5.8 \pm 0.19 \%(p<0.05)$. Curvilinear
\end{abstract}

Received December 30, 1983; accepted October 3, 1984.

Reprint requests Sherin U. Devaskar, M.D., Room No. 519, Glennon Hall, 1465, S. Grand Boulevard, St. Louis, MO 63104.

Supported in part by the American Heart Association-Missouri Affiliate, The National American Diabetes Association and the Biomedical Research Support Grant (NIH RR05388).
Scatchard plots revealed an increase in receptor number $x$ $10^{7} \mu$ protein $^{-1}$ from $137 \pm 4$ to $244 \pm 39(p<0.05)$ with no change in receptor affinity. No appreciable alteration by $\mathrm{T} 4$ in the $\left[{ }^{125}\right.$ I]insulin-specific binding and receptor number of 30-day fetal brains was noted. Fetal heart glycogen content was decreased and there was a small increase in plasma glucose concentration in the T4-treated group (each $p<0.02$ ). Betamethasone at $0.17 \mathrm{mg} / \mathrm{kg}$ did not affect the specific binding of $\left[{ }^{125} \mathrm{I}\right]$ insulin to 27 -day fetal heart or brain plasma membranes, although a decrease in heart glycogen content and an increase in plasma glucose concentration were observed (each $p<0.02$ ). Also T4 + betamethasone did not alter the ${ }^{[25}$ I] insulin binding to 27 day fetal heart or brain plasma membranes, but resulted in an additive effect (a marked depletion) on cardiac glycogen $(p<0.001)$. Brain glycogen was undetectable in all 
fetuses, control or treated (regardless of the type of hormonal treatment). Thus $\mathrm{T} 4$ and glucocorticoids produce different effects on developing fetal brain and heart insulin receptors, along with a depletion of the myocardial glycogen stores. (Pediatr Res 19: 192-198, 1985)

Abbreviations

T4, thyroxine
T3, triiodothyronine

Glucose is an essential fuel for the metabolism of vital organs such as the brain and the heart $(5,36)$. Insulin promotes glucose uptake in various adult $(9,6,28)$ and fetal tissues $(30)$. Since the biologic effects of insulin are mediated by binding to specific tissue receptors, a change in the physical characteristics of these receptors as well as changes in postreceptor events may influence fetal anabolic processes (24). Hormones that antagonize the effects of insulin modulate insulin receptor characteristics in both the adult $(2,12,16,25)$ and fetus $(11,34)$. Insulin influences the growth and metabolism of fetal organs $(18,30)$. T4 and glucocorticoids may modify this effect of insulin, since both these hormones have been demonstrated to alter the insulin receptors $(10,11,34)$.

In the human fetus, glucocorticoids are administered to stimulate surfactant synthesis (19) and the use of thyroid hormones is contemplated in situations where the effect of glucocorticoids is limited $(14,21)$. It is therefore important to define the effects of these hormones on other organs in the fetus. In this study, we investigated the influence of $\mathrm{T} 4$ and glucocorticoids on the maturation of the insulin receptor along with certain metabolic events in two vital organs, the fetal brain and heart.

\section{MATERIALS AND METHODS}

Animals. Pregnant New Zealand White rabbits of known gestation (term $\sim 31$ days) were assigned to one of the five groups: 1) T4 treatment (30 days gestation $-n=7 ; 27$ days $-n=3) ; 2$ ) control I $(n=6) ; 3)$ steroid treatment $(n=6)$; 4) control II $(n=$ $6)$; and 5) T4 and steroid treatment $(n=4)$.

The T4 treatment group of animals $(n=7)$ received intramuscular injections of $\mathrm{T} 4$ at $50 \mu \mathrm{g} / \mathrm{kg}$ body weight every other day for a total of five injections from day 21 to 29 of gestation. This dose is approximately three times the dose reported to maintain a maternal euthyroid state in does rendered hypothyroid with propylthiouracil (11).

Another small group of pregnant rabbits $(n=3)$ received a total of five doses of T4 ( $50 \mu \mathrm{g} / \mathrm{kg}$ every other day) between days 18 and 26 of gestation. This group was included to compare the effects of T4 on 27-and 30-day-old fetuses. Animals in this small subgroup were sacrificed at 27 day of gestation. Control I animals received $0.1 \mathrm{ml}$ of normal saline on alternate days between days 21 and 29 of gestation.

The steroid-treated animals received betamethasone $(0.085$ $\mathrm{mg} / \mathrm{kg}$ ) on days 25 and 26 of gestation. This dose has been shown to suppress endogenous maternal and fetal corticosteroid production and modulate fetal lung and liver insulin receptors without altering fetal plasma insulin concentrations $(11,34)$. Control II animals received two $0.1 \mathrm{ml}$ intramuscular injections of normal saline on days 25 and 26 of gestation.

The T4 plus steroid treatment group of pregnant does $(n=4)$ received $50 \mu \mathrm{g} / \mathrm{kg}$ of T4 every other day (a total of five doses) from day 18 to 26 of gestation. In addition on days 25 and 26 of gestation these animals received $0.085 \mathrm{mg} / \mathrm{kg} / \mathrm{dose}$ of betamethasone.

The T4 treated and control I animals were sacrificed on day 30 of gestation. The steroid treated, control II and T4 + steroid treated animals were sacrificed on day 27.
Immediately prior to sacrifice, maternal arterial blood was collected. Animals were sacrificed by intravenous pentobarbitone; fetal (free flowing) blood was collected after decapitation for measurements of plasma glucose, free T4, total T3, and insulin concentrations (11). Fetal blood collected in this manner yields results comparable to values reported previously by us (11, 34) and other investigators (23).

Plasma membranes. Brain plasma membranes were prepared by the method of Havrankova and Roth (15) and cardiac plasma membranes by the method of Rockson et al. (27). Briefly fetal brains from a litter were removed from the cranium and pooled prior to homogenization in a Dounce glass homogenizer containing $1 \mathrm{mM}$ bicarbonate buffer $(\mathrm{pH} 8.0)$. The homogenate was centrifuged at $600 \times g$ for $10 \mathrm{~min}$ at $4^{\circ} \mathrm{C}$. The pellet was discarded and the supernatant centrifuged at $20,000 \times g$ for 30 min. The final pellet was resuspended in 1 volume of $50 \mathrm{mM}$ Tris buffer for every gram of original brain weight.

Hearts from a litter (two litters when there was insufficient tissue) were pooled, trimmed, minced, and homogenized in 10 vol of $0.25 \mathrm{M}$ Tris, $1 \mathrm{mM} \mathrm{MgCl} 2,5 \mathrm{mM}$ EGTA using a Dounce glass homogenizer. After filtering through two layers of cheesecloth, the homogenate was centrifuged at $3000 \times g$ for $10 \mathrm{~min}$. The pellet was resuspended in $0.75 \mathrm{ml}$ of buffer per gram of original heart weight.

Protein concentration of both the brain and heart homogenates and membranes was estimated by the method of Lowry (20). Organ DNA content was determined by Zamenof's modification (38) of Burton's technique (4). 5'-Nucleotidase activity in brain and heart homogenates, brain plasma membranes, and heart plasma membranes was measured as described before (1). The 5 '-nucleotidase activity in all membranes studied was unchanged, regardless of T4 or steroid treatment. In comparison with the respective tissue homogenates, a 2-fold enrichment of the enzyme activity in the brain plasma membranes and a 1.6fold enrichment in the heart plasma membrane was observed. Brain, heart, and liver glycogen was quantified by hydrolysis and estimation of glucose (26).

Insulin binding assay. The $\left[{ }^{125} \mathrm{I}\right]$ insulin binding assay was performed as described previously (11), with the exception of the final assay $\mathrm{pH}$ ( 8.0 for the brain and 7.4 for the heart) (Fig. 1). In addition $\sim 70,000 \mathrm{cpm}$ of labeled insulin (specific activity $\sim 100$ to $150 \mathrm{mCi} / \mathrm{mg}$ ) for the brain and $\sim 35,000 \mathrm{cpm}$ for the heart were used as the ligand. Membrane protein concentrations of 50 to $100 \mu \mathrm{g}$ (heart) and $200 \mu \mathrm{g}$ (brain) per tube were used. Scatchard plots of insulin binding data were used to determine total binding capacities (R0) and mean association constants (Ke) for receptors (29). The curvilinear Scatchard plots were resolved into two components, a high affinity low capacity component (R1) and low affinity high capacity component (R2). The association constants (K1 and $\mathrm{K} 2$ ) for these two components, respectively, also were calculated (35). Binding capacities in mol/liter were converted to number of receptors per microgram protein.

Other assays. Plasma glucose was measured by a glucose oxidase method (11). Plasma insulin (33) and serum-free T4 concentrations (33) were determined by specific radioimmunoassays as described previously. Serum total T3 concentrations were measured using a T3 immunophase RIA kit (Corning Medical, Medfield, MA). The sensitivity of the assay is $0.1 \mathrm{ng} /$ $\mathrm{ml}$. Interassay and intraassay coefficient of variation was less than $4 \%$. The antibody cross-reacts $100 \%$ with L-triiodothyronine, $72 \%$ with $\mathrm{D}$-triiodothyronine, $27 \%$ with triiodothyroacetic acid, $0.14 \%$ with D-thyroxine, and $0.12 \%$ with $L$-thyronine.

Statistics. All data are presented as a mean \pm SEM. Statistically significant differences between the treated and the respective control groups was determined by the two-tailed Student's $t$ test. Analysis of variance was employed when more than two groups were compared simultaneously. Correlation between the maternal and fetal plasma-free T4 concentrations in the T4-treated group of animals was determined by linear regression analysis. 


\section{RESULTS}

Table 1 lists the fetal body weights and mean brain and heart weights. No differences in fetal body, brain, or heart weights were observed in the T4-treated and control I groups. The steroidtreated fetuses weighed $(21.54 \pm 1.34 \mathrm{~g})$ less than the control II animals $(28.85 \pm 2.21 \mathrm{~g}, p<0.02)$. The $\mathrm{T} 4+$ steroid-treated animals were intermediate in weight $(25.39 \pm 2.46)$ between the steroid-treated and control II groups; the mean weights were statistically similar in the three groups. As expected, the fetal body and organ weights were greater at 30 days than at 27 days of gestation. In addition, both the brain and heart DNA contents were similar in the T4-treated group and the T4 + steroid-treated group when compared to their respective controls. Heart DNA content decreased from $1.82 \pm 0.06$ to $1.43 \pm 0.12 \mathrm{mg} / \mathrm{g}(p<$ 0.02 ), in response to steroid treatment; there was no change in brain DNA content in response to steroid treatment. The protein content as described in other organs (37) increased from 51.58 \pm 1.98 to $56.63 \pm 0.68 \mathrm{mg} / \mathrm{g}(p<0.05)$ in the T4-treated fetal

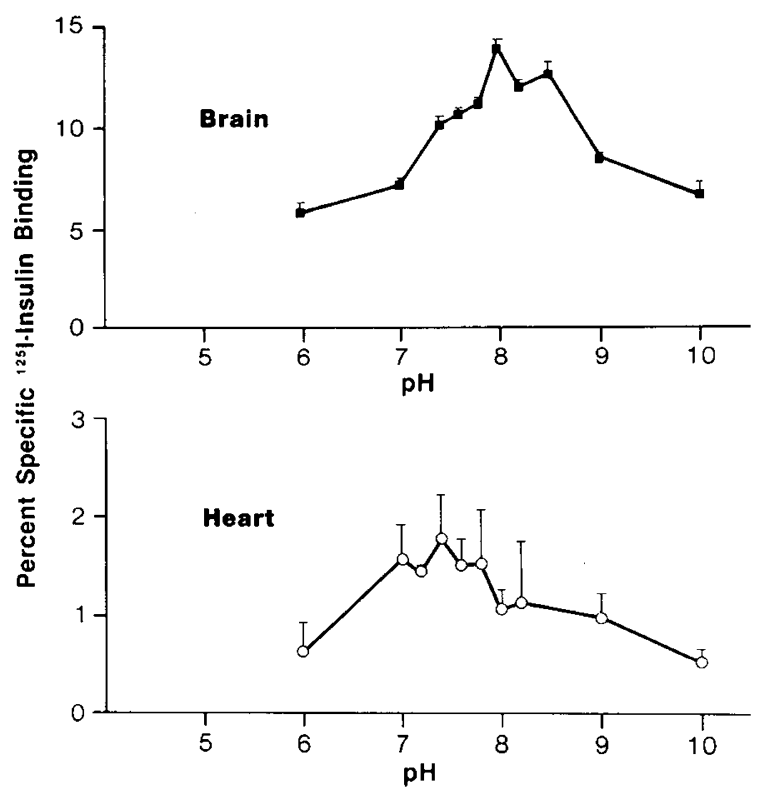

Fig. 1. Specific binding of $\left[{ }^{125} \mathrm{I}\right]$ insulin to fetal brain and heart at various $\mathrm{pH}$. The final $\mathrm{pH}$ used in the assays were peak values: 8.0 for the brain and 7.4 for the heart plasma membranes. brain and from $89.17 \pm 4.08$ to $105.9 \pm 3.5 \mathrm{mg} / \mathrm{g}(p<0.02)$ in the T4-treated fetal hearts. A similar increase was observed in both organs in response to $\mathrm{T} 4+$ steroid treatment. Steroid treatment alone, however, did not alter brain or heart protein content.

Plasma glucose and plasma/serum hormone concentrations are depicted in Table 2. T4 treatment increased fetal plasma glucose concentrations $(47 \pm 4.9$ to $69 \pm 4.7 \mathrm{mg} / \mathrm{dl}, p<0.02)$ with no change in maternal concentrations. A marked increase in plasma glucose concentrations from $57 \pm 4.8$ to $124 \pm 12.4$ $\mathrm{mg} / \mathrm{dl}(p<0.02)$ and $101 \pm 14.5 \mathrm{mg} / \mathrm{dl}(p<0.02)$ in the steroid treated and $\mathrm{T} 4+$ steroid treated fetuses, respectively, was observed with no alteration in maternal values. Fetal plasma insulin concentrations were not altered by $\mathrm{T} 4$, steroid, or $\mathrm{T} 4+$ steroid treatment.

Serum-free T4 concentrations increased from a control value of $0.21 \pm 0.02$ to $0.75 \pm 0.08 \mathrm{ng} / \mathrm{dl}(p<0.02)$ in the 30-day gestation animals and from $0.06 \pm 0.02$ to $0.31 \pm 0.07(p<$ 0.02 ) in the 27-day gestation T4-treated fetuses (not shown in Table 2). The maternal serum-free $\mathrm{T} 4$ values were $5.41 \pm 0.55$ at 30 days (control $\mathrm{I}=0.87 \pm 0.33 \mathrm{ng} / \mathrm{dl}, p<0.001$ ) and 2.31 \pm 0.27 at 27 days (control II $=0.53 \pm 0.06$ ) in the T4-treated animals. When fetal serum-free T4 values were plotted against maternal values in the T4-treated group (30 days), a linear correlation was noted $(y=0.1248 x+0.0739, r=0.86)$. The maternal to fetal plasma-free $\mathrm{T} 4$ concentration ratio in the T4treated group was $8: 1$. Serum total T3 increased from a control value of $0.76 \pm 0.03$ to $1.17 \pm 0.02 \mathrm{ng} / \mathrm{ml}$ in the T4-treated and to $1.08 \pm 0.25 \mathrm{ng} / \mathrm{ml}$ in the $\mathrm{T} 4+$ steroid-treated groups. Maternal serum total T3 was greater than $10 \mathrm{ng} / \mathrm{ml}$ in both groups (control $=2.31 \pm 0.27)$. These data indicate significant transplacental transfer of free $\mathrm{T} 4$ to the fetus during the administration of a pharmacologic dose of $\mathrm{T} 4$ to the mother. Administration of steroid alone resulted in an increase in serum free $\mathrm{T} 4$ levels in the fetus from $0.06 \pm 0.02$ to $0.33 \pm 0.03(p<0.001)$.

Figure 2 demonstrates the $\left[{ }^{125} \mathrm{I}\right]$ insulin competition curves in both the fetal T4-treated and control I brain and heart membranes. The mean \pm SEM are represented in these curves. In the inset Scatchard plots (mean values) are represented. The Scatchard plot data obtained are summarized in Table 3. Using brain plasma membranes, no difference in percent specific $\left[{ }^{125} I\right]$ insulin binding (Fig. 2, Table 3), R0, R1, and R2 is observed between the T4-treated and control I fetuses. Conversely in the T4-treated heart plasma membranes, an increase from $3.6 \pm 0.74$ to $5.8 \pm$ $0.19 \%(p<0.05)$ in $\left[{ }^{125} \mathrm{I}\right]$ insulin binding is noted. In addition an increase in the total receptor number (R0) from $137 \pm 3.9$ to

Table 1. Fetal body wt, organ wt, protein, and DNA content

\begin{tabular}{|c|c|c|c|c|c|c|c|c|}
\hline \multirow{2}{*}{$\begin{array}{l}\text { Groups } \\
(n)\end{array}$} & & \multirow{2}{*}{$\begin{array}{c}\text { Fetal body } \\
\text { wt (g) }\end{array}$} & \multirow{2}{*}{$\begin{array}{c}\text { Fetal brain } \\
\text { wt (g) }\end{array}$} & \multirow{2}{*}{$\begin{array}{c}\text { Fetal heart } \\
\text { wt }(\mathrm{g})\end{array}$} & \multicolumn{2}{|c|}{$\begin{array}{l}\text { Protein content } \\
\quad(\mathrm{mg} / \mathrm{g})\end{array}$} & \multicolumn{2}{|c|}{$\begin{array}{l}\text { DNA content } \\
(\mathrm{mg} / \mathrm{g})\end{array}$} \\
\hline & & & & & Brain & Heart & Brain & Heart \\
\hline \multicolumn{9}{|l|}{ 30-day } \\
\hline T4-treated group & $\overline{\mathrm{X}}$ & 44.05 & 1.08 & 0.23 & $56.63^{*}$ & $105.9 \dagger$ & 1.24 & 2.28 \\
\hline$(n=6)$ & SEM & 2.89 & 0.05 & 0.02 & 0.68 & 3.5 & 0.04 & 0.24 \\
\hline Control I group & & 51.78 & 1.12 & 0.19 & 51.58 & 89.17 & 1.23 & 2.10 \\
\hline$(n=7)$ & & 2.68 & 0.04 & 0.02 & 1.98 & 4.08 & 0.06 & 0.26 \\
\hline \multicolumn{9}{|l|}{ 27-day } \\
\hline Steroid-treated group & & $21.54 \dagger$ & 0.51 & 0.13 & 61.70 & 47.50 & 1.26 & $1.43 \dagger$ \\
\hline$(n=6)$ & & 1.34 & 0.04 & 0.01 & 3.49 & 2.04 & 0.13 & 0.12 \\
\hline Control II group & & 28.85 & 0.62 & 0.14 & 63.12 & 54.70 & 1.43 & 1.82 \\
\hline$(n=6)$ & & 2.21 & 0.06 & 0.03 & 1.76 & 3.02 & 0.05 & 0.06 \\
\hline $\mathrm{T} 4$ + steroid-treated & & 25.39 & 0.53 & 0.13 & $71.63^{*}$ & $62.66^{*}$ & 1.49 & 2.53 \\
\hline $\begin{array}{l}\text { group } \\
(n=4)\end{array}$ & & 2.46 & 0.03 & 0.04 & 4.85 & 5.20 & 0.02 & 0.49 \\
\hline
\end{tabular}

${ }^{*} p<0.05$, when compared to controls.

$\dagger p<0.02$, when compared to controls. 
Table 2. Fetal plasma glucose and insulin, serum-free T4, and total T3 concentrations

\begin{tabular}{|c|c|c|c|c|c|}
\hline $\begin{array}{c}\text { Groups } \\
(n)\end{array}$ & & $\begin{array}{l}\text { Plasma glucose } \\
\qquad(\mathrm{mg} / \mathrm{dl})\end{array}$ & $\begin{array}{l}\text { Plasma insulin } \\
\qquad(\mu \mathrm{U} / \mathrm{ml})\end{array}$ & $\begin{array}{l}\text { Serum-free T4 } \\
(\mathrm{ng} / \mathrm{dl})\end{array}$ & $\begin{array}{l}\text { Serum total T3 } \\
(\mathrm{ng} / \mathrm{ml})\end{array}$ \\
\hline T4-treated & Mean & $69^{*}$ & 20.1 & $0.75^{*}$ & \\
\hline group-30 days & SEM & 4.7 & 3.0 & 0.08 & \\
\hline$(n=6)$ & & $(115 \pm 6.8) \dagger$ & & $(5.41 \pm 0.55) \dagger$ & \\
\hline \multirow[t]{2}{*}{$(n=3)-27$ days $\ddagger$} & & 67 & 53.4 & $0.76^{*}$ & $1.17^{*}$ \\
\hline & & $\begin{array}{c}9.5 \\
(135 \pm 6.5) \dagger\end{array}$ & 12.6 & $\begin{array}{l}0.03 \\
(2.31 \pm 0.27) \dagger\end{array}$ & $\begin{array}{l}0.02 \\
(>10) \dagger\end{array}$ \\
\hline Control I & & 47 & 26.2 & 0.21 & \\
\hline group -30 days & & 4.9 & 4.0 & 0.02 & \\
\hline$(n=7)$ & & $(111 \pm 2.7) \dagger$ & & $(0.87 \pm 0.03) \dagger$ & \\
\hline Steroid-treated & & $124^{*}$ & 17.5 & $0.33^{*}$ & \\
\hline $\begin{array}{l}\text { group-27 days } \\
(n=6)\end{array}$ & & $\begin{array}{l}12.4 \\
(166 \pm 23.9) \dagger\end{array}$ & 7.5 & 0.03 & \\
\hline Control II-27 days & & 57.3 & 37.5 & 0.06 & 0.76 \\
\hline$(n=6)$ & & 4.8 & 6.5 & 0.02 & 0.03 \\
\hline & & $(126 \pm 4.4) \dagger$ & & $(0.53 \pm 0.06) \dagger$ & $(2.31 \pm 0.27)$ \\
\hline $\mathrm{T} 4+$ steroid -27 days & & $101^{*}$ & 22.9 & $0.36^{*}$ & $1.08^{*}$ \\
\hline treated group & & 14.5 & 5.2 & 0.01 & 0.25 \\
\hline$(n=4)$ & & $(142 \pm 6.8) \dagger$ & & $(3.51 \pm 0.39) \dagger$ & $(>10) \dagger$ \\
\hline
\end{tabular}

${ }^{*} p<0.02$, when compared to controls.

$\dagger$ Maternal values are represented in parentheses.

¥ The 27 days T4-treated subgroup was compared with control II.

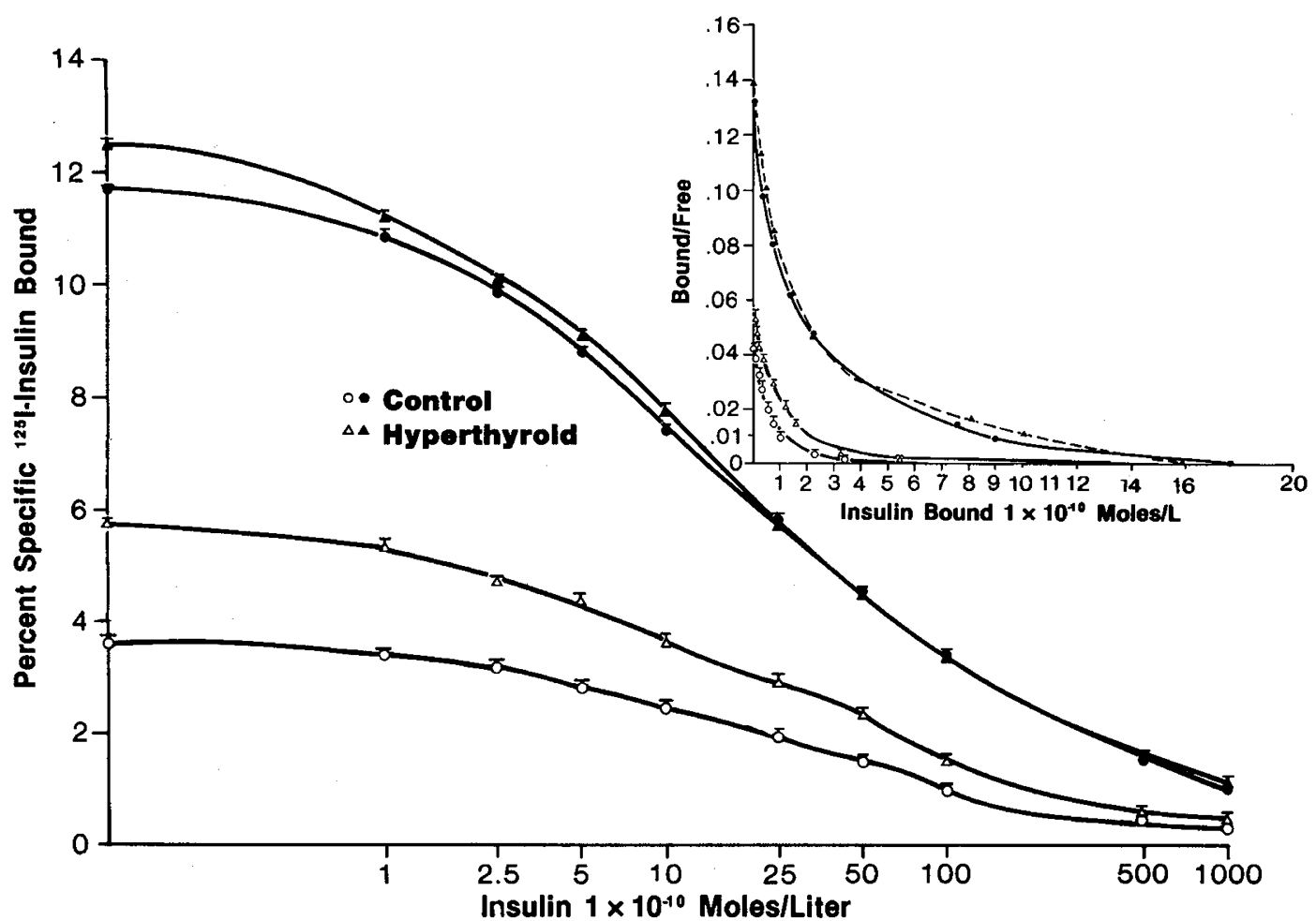

Fig. 2. Competition curves of $\left[{ }^{125} I\right]$ insulin are represented with the respective Scatchard plots in the inset: 30-day gestation T4-treated fetal brain (solid triangles) and heart (open triangles) plasma membranes versus control fetal brain (solid circles) and heart (open circles) plasma membranes.

$244 \pm 39.2 \times 10^{7} \mu \mathrm{g}$ protein $^{-1}(p<0.02)$ and the low affinity, high capacity $(R 2)$ receptor sites is observed. No change in the high affinity, low capacity $(\mathrm{R} 1)$ receptor number is demonstrated. In both the brain and heart the affinity constants remained unchanged. Similar $\left[{ }^{125} \mathrm{I}\right]$ insulin binding results were observed in the T4-treated 27-day-old subgroup of fetuses $(n=3)$. No significant difference was observed between the two gestational ages.

Steroid treatment (Table 4) did not alter the [ $\left.{ }^{125} I\right]$ insulin binding to fetal brain (10.3 $\pm 0.41 \%$ versus a control of $9.2 \pm$ $0.52 \%)$ and heart $(3.4 \pm 0.24 \%$ versus a control of $3.5 \pm 0.33 \%)$.
Similarly T4 + steroid treatment did not alter the $\left[{ }^{125}\right.$ I] insulin binding to the fetal brain $(9.3 \pm 0.61 \%)$ and fetal heart $(4.3 \pm$ $0.13 \%$ ) although in the latter binding was intermediate between the control and T4-treated values.

Figure 3 demonstrates the total glycogen content in $\mu \mathrm{M}$ glucosyl units/mg protein of heart in addition to the specific $\left[{ }^{125} \mathrm{I}\right]$ insulin binding to myocardial membranes. Contrary to the change in [ $\left.{ }^{125} \mathrm{I}\right]$ insulin binding and total receptor number, a decrease in fetal cardiac glycogen from $0.65 \pm 0.04$ to $0.46 \pm$ $0.01 \mu \mathrm{M}$ glucosyl units/mg protein $(p<0.02)$ is observed in 
Table 3. Insulin receptor characteristics in 30-day fetal brain and heart plasma membranes

\begin{tabular}{|c|c|c|c|c|c|c|c|c|}
\hline \multirow{2}{*}{$\begin{array}{c}\text { Groups } \\
(n)\end{array}$} & & \multirow{2}{*}{$\begin{array}{c}\% \text { Specific binding of } \\
{\left[{ }^{125} \mathrm{I}\right] \text { insulin per } 100 /} \\
200 \mu \mathrm{g} \text { protein }\end{array}$} & \multicolumn{3}{|c|}{$\begin{array}{l}\text { Receptor no. } \times 10^{7} \mu \mathrm{g} \\
\text { protein }^{-1}\end{array}$} & \multicolumn{3}{|c|}{ Affinity constant $\times 10^{7} \mathrm{M}$} \\
\hline & & & Ro & $\mathrm{R} 1$ & $\mathrm{R} 2$ & $\mathrm{Ke}$ & $\mathrm{K} 1$ & $\mathrm{~K} 2$ \\
\hline T4-treated & $\overline{\mathrm{x}}$ & 12.5 & 153 & 8.2 & 145 & 9.91 & 123 & 2.60 \\
\hline $\begin{array}{l}\text { brains } \\
(n=6)\end{array}$ & SEM & 0.5 & 10.0 & 1.0 & 9.9 & 0.61 & 12.1 & 0.41 \\
\hline Control I & & 11.7 & 186 & 15.2 & 171 & 7.87 & 86 & 1.53 \\
\hline $\begin{array}{c}\text { brains } \\
(n=7)\end{array}$ & & 0.6 & 14.8 & 2.4 & 15.0 & 0.86 & 9.0 & 0.41 \\
\hline T4-treated & & $5.8^{*}$ & $244^{*}$ & 10.8 & $233 \dagger$ & 5.80 & 189 & 0.60 \\
\hline $\begin{array}{l}\text { hearts } \\
(n=4)\end{array}$ & & 0.2 & 39.2 & 5.7 & 36.7 & 1.29 & 85.0 & 0.10 \\
\hline Control I & & 3.6 & 137 & 11 & 126 & 5.75 & 85 & 0.60 \\
\hline $\begin{array}{l}\text { hearts } \\
(n=5)\end{array}$ & & 0.7 & 3.9 & 4.0 & 2.7 & 0.81 & 16.3 & 0.10 \\
\hline
\end{tabular}

${ }^{*} p<0.05$, when compared to controls.

$\dagger p<0.02$, when compared to controls.

Table 4. \% Specific binding of $\int^{125}$ I]insulin to 27-day fetal brain and heart plasma membranes

\begin{tabular}{lcc}
\hline \multicolumn{1}{c}{ Groups } & $\begin{array}{c}\text { Brain } \\
(\text { per } 200 \mu \mathrm{g})\end{array}$ & $\begin{array}{c}\text { Heart } \\
(\text { per } 100 \mu \mathrm{g})\end{array}$ \\
\hline Steroid treated & $10.3(6)^{*}$ & $3.4(4)$ \\
& 0.41 & 0.24 \\
Control II & $9.2(6)$ & $3.5(5)$ \\
& 0.52 & 0.33 \\
T4 + steroid treated & $9.3(4)$ & $4.3(4)$ \\
& 0.61 & 0.13 \\
\hline
\end{tabular}

* The numbers in parentheses denote the number of pooled brains/ hearts.

response to T4 treatment. Steroid treatment also decreased the fetal myocardial glycogen content from $0.80 \pm 0.31$ to $0.68 \pm$ $0.02 \mu \mathrm{M}$ glucosyl units/mg protein $(p<0.02)$. T4 + steroid treatment similarly decreased the glycogen content in the heart to $0.07 \pm 0.005(p<0.001)$. Myocardial glycogen content, expressed as $\mu \mathrm{M}$ glucosyl units $/ \mu \mathrm{g}$ DNA, decreased from 0.020 \pm 0.0001 in the 30-day control fetus to $0.015 \pm 0.001(p<0.01)$ in the T4-treated fetus. Similarly a decrease from $0.17 \pm 0.01$ in the 27-day control fetus to $0.12 \pm 0.005(p<0.02)$ and 0.0016 $\pm 0.0002(p<0.001)$ in the steroid-treated and T4 + steroidtreated fetuses, respectively, was observed. Total brain glycogen content in all five groups was less than the sensitivity of the assay and thus undetectable. The sensitivity of the glycogen assay is $0.025 \mu \mathrm{M}$ glucosyl units $/ 100 \mu \mathrm{l}$ or $0.1 \mathrm{~g}$ of brain tissue. Glycogen content in both organs was measured as an end product of insulin-regulated glucose uptake by myocardial and brain cells. In addition, fetal liver glycogen content was quantified and noted to be no different in the T4-treated and control I groups (215 \pm 11.8 versus $210 \pm 8.8 \mu \mathrm{M}$ glucosyl units/g wet weight).

\section{DISCUSSION}

Previously we demonstrated that administration of T4 at 25 $\mu \mathrm{g} / \mathrm{kg}$ every other day for a total of three doses $(75 \mu \mathrm{g} / \mathrm{kg})$ to hypothyroid pregnant does rendered them euthyroid, without affecting the low fetal-free T4 levels (11). However, in the present study, we observed that administration of a higher dose of T4 to euthyroid pregnant does (total of $250 \mu \mathrm{g} / \mathrm{kg}$ ) results in high maternal and fetal-free T4 levels. The high serum T4 levels exert a biologic effect in the fetus. In addition we demonstrated an increase in cardiac insulin receptors with a decrease in glycogen content in the T4-treated fetuses. Our results are consistent with

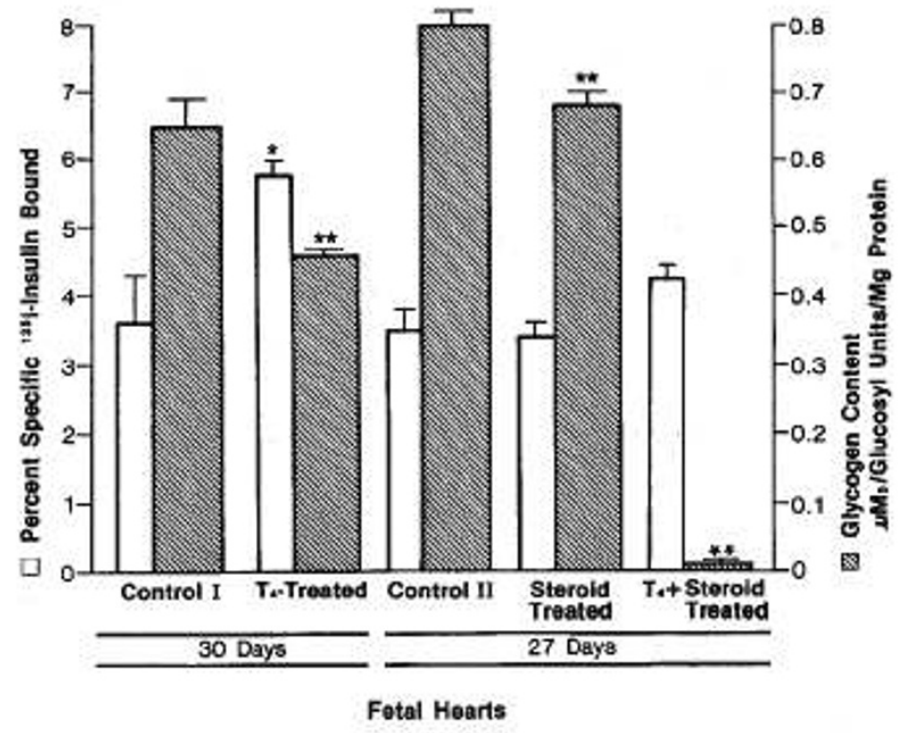

Fig. 3. Percent $\left[{ }^{125} I\right]$ insulin binding to heart plasma membranes and myocardial glycogen content in $\mu$ mol glucosyl units/mg protein in control I and T4-treated 30-day gestation fetuses; and in control II, steroidtreated, and T4 + steroid-treated 27-day gestation fetuses. $p^{*}<0.05$, ${ }^{* *}$ $<0.02$, when compared to their respective gestational age-matched control group.

previous observations that $\mathrm{T} 4$ increased the insulin receptor number of adult adipocytes (16) and hypothyroidism was associated with a decrease in fetal lung and liver insulin receptors $(11,34)$.

Following maternal administration of a synthetic thyroxine preparation, 3,5, dimethyl $3^{\prime}$ isopropyl thyronine, which more readily crosses the placenta, a depletion in fetal myocardial glycogen has been observed (23). In the present study, no effect of the T4 treatment on fetal liver glycogen content was observed. In a preliminary experiment $(n=6)$, at twice the dose of T4 administered in this study (i.e. $500 \mu \mathrm{g} / \mathrm{kg}$ ), we observed a depletion of fetal liver glycogen (7). These observations suggest that in the fetus, myocardial glycogen is more sensitive than liver glycogen to the effects of T4.

In the adult heart, insulin specifically promotes glycogen synthesis by increasing the glycogen synthase enzyme activity with little or no effect on phosphorylase activity (22). However, the phosphorylase enzyme system is hypersensitive to insulin antag- 
onists, e.g. $\alpha$ and $\beta$ adrenergic agonists and glucagon (17). Plasma insulin concentrations remaining constant and an increase in insulin receptor number with unchanging postreceptor events should increase the biologic effect of insulin and augment glucose uptake. This has been demonstrated in the adult (24). However, the fetus is relatively resistant to insulin; peripheral glucose uptake increases only when pharmacologic doses of insulin are administered (30), and glucose challenge produces a relatively obtunded insulin response (32). In addition, a delayed maturation of insulin-induced glucose uptake versus amino acid uptake has been demonstrated in fetal hepatocytes (31).

Besides an increase in the myocardial insulin receptor number, the effect of T4 on various enzymes regulating glycogen synthesis is not clear. An activation of myocardial phosphorylase and an acceleration of glycogen depletion coincides with the postnatal period of physiologic T4 surge in the neonate (13). T4 (3,5,dimethyl $3^{\prime}$ isopropyl thyronine) also evokes a depletion of myocardial glycogen in a hyperinsulinemic fetus of an alloxandiabetic mother (23). This suggests that T4 alters the enzyme activity that controls glycogen metabolism. The influence of T4 on postreceptor events may be responsible for the depletion of myocardial glycogen. $T 4$, by independently modulating the insulin receptor and postreceptor action(s), thus dissociates the physical characteristics of the receptor and the biologic function. In association with the decrease in cardiac glycogen stores, a slight increase in fetal plasma glucose concentration was noted in the present study. No similar change in maternal glucose values was observed possibly due to the dilutional effect in the large maternal pool. Again an increase in fetal plasma glucose values did not stimulate a rise in fetal insulin concentrations, due to an obtunded fetal pancreatic islet cell response to a glucose challenge (32).

During the same developmental period, no modulation by $\mathrm{T} 4$ of fetal brain insulin binding or receptor number was observed. Most biochemical events of physiologic significance in the brain, such as the synthesis of myelin lipids, occur postnatally (8). In the presence of a change in cardiac insulin receptor number, an absence of a change in brain insulin receptor characteristics signifies a difference in organ maturity or a different response by separate organs to the same stimulus.

Glucocorticoid treatment did not change fetal cardiac $\left[{ }^{125} \mathrm{I}\right]$ insulin binding despite elevated serum-free T4 concentrations. Although the free T4 levels after steroid treatment were similar to the levels achieved with T4 treatment alone, no increase in the insulin binding akin to that observed in response to T4 treatment alone was demonstrated. On the contrary, the steroidinduced decrease in $\left[{ }^{125} \mathrm{I}\right]$ insulin binding and receptor number observed in the fetal liver (34) was absent in the myocardium. The influence of high $\mathrm{T} 4$ concentrations was masked by the effect of the steroids in the fetus. In addition, a reduction in the heart glycogen content along with an increase in fetal glucose concentrations was noted in response to steroid treatment alone. Although during development changes in the fetal liver insulin receptor characteristics secondary to steroid treatment have been demonstrated (34), the lack of change in brain $\left[{ }^{125} \mathrm{I}\right]$ insulin binding may again be due to organ maturational differences.

$\mathrm{T} 4+$ steroid treatment also resulted in an absence of a change in either the fetal myocardial or the brain $\left[{ }^{125} \mathrm{I}\right]$ insulin binding. However, a marked depletion of myocardial glycogen with an elevation of plasma glucose levels was observed as an additive effect of T4 and steroids.

Our studies demonstrate that the fetal brain insulin receptor is not modulated by the systemic hormonal changes that modulate the cardiac receptor. This suggests a relative unresponsiveness on the part of fetal neural tissue. On the other hand, in the fetal myocardium, combined T4 and steroid treatment neutralize the effect of either hormone alone on insulin binding (an increase in number by $\mathrm{T} 4$ and an absence of a decrease by steroids).

Although the physiologic significance remains unclear, we have demonstrated an additive interaction between $\mathrm{T} 4$ and be- tamethasone with regard to myocardial glycogen depletion. The sensitive period for a $\mathrm{T} 4$ effect on human fetal insulin receptors has not been defined; besides 10 days of T4 therapy in the rabbit fetus cannot be related to the clinical situation. However, our present studies stress the need for more information about other effects, since combined thyroid hormone and glucocorticoid therapy has recently been proposed in the amelioration of respiratory distress syndrome in the impending delivery of a premature infant (21).

Acknowledgments. We thank N. Holekamp and N. Marino for their technical assistance.

\section{REFERENCES}

1. Arkesteijn CLM 1976 A simple method for the measurement of 5 -nucleotidase activity. J Clin Chem Clin Biochem 14:155-160

2. Arner P, Bolinder J, Wennlund A, Ostman J 1984 Influence of thyroid hormone level on insulin action in human adipose tissues. Diabetes 33:369375

3. Bassett JM, Jones CT 1976 Fetal glucose metabolism. In: Beard RW, Nathanielsz PW (eds) Fetal Physiology and Medicine. WB Saunders Co, Philadelphia, pp 158-172

4. Burton K 1956 A study of the condition and mechanism of the diphenylamine reaction for the colorimetric estimation of deoxyribonucleic acid. Biochem J 62:315-323

5. Cahill GF Jr 1970 Starvation in man. N Engl J Med 282:668-675

6. Capeau J, Glaig-Staedel C, Beck J, Picard J 1983 Insulin induced receptor regulation in cultured Zajdela rat hepatoma cells and relationship to the stimulation of glycogen synthesis. Endocrinology 111:993-1000

7. Church J, Devaskar SU, Sadiq HF, Devaskar UP 1984 Effect of betamethasone, thyroxine, triiodothyronine on fetal glucose-glycogen metabolism. (in press) (abstr)

8. Cuaron A, Gamble J, Myant NB, Oscorio C 1963 The effect of thyroid deficiency on the growth of the brain and on the deposition of brain phospholipids in fetal and newborn rabbits. J Physiol 268:613-630

9. Czech MP 1977 Molecular basis of insulin action. Ann Rev Biochem 46:359384

10. Czech MP, Malbon CC, Kerman K, Gitomer W, Pilch PF 1980 Effect of thyroidal status on insulin action in rat adipocytes and skeletal muscle. $J$ Clin Invest 66:574-582

11. Devaskar SU, Ganguli S, Devaskar UP, Sperling MA 1982 Glucocorticoids and hypothyroidism modulate development of fetal lung insulin receptors. Am J Physiol 242:E384-E391

12. Fantus IG, Ryan J, Hizuka N, Gordon P 1981 The effect of glucocorticoids on the insulin receptor: an in vivo and in vitro study. $\mathrm{J}$ Clin Endocrinol Metab 52:953-960

13. Fisher DA, Klein AH 1980 The ontogenesis of thyroid function and its relationship to neonatal thermogenesis. In: Tulchinsky EE, Ryan KJ (eds) Fetal-Maternal Endocrinol 15:281-293

14. Gross I, Dynia DW, Wilson CM, Gewolb IH, Rooney SA 1984 Glucocorticoids-thyroid interaction in fetal rat lung. Pediatr Res 18:191-196

15. Havrankova J, Roth J 1979 Concentrations of insulin and of insulin receptors in the brain are independent of peripheral insulin levels. Studies of obese and streptozotocin treated rodents. J Clin Invest 64:636-642

16. Heise H, Joost HG, Hasselblatt A 1982 Insulin binding and response to insulin of adipocytes from thyroxine treated rats. Endocrinology 110:955-960

17. Ingebretsen CG 1981 Diabetes alters the myocardial c-AMP protein kinase cascade system. Am J Physiol 240 (Heart Circ Physiol 9):H375-H382

18. Jones CT 1976 Fetal metabolism and fetal growth. J Reprod Fertil 47:189199

19. Liggins GC, Howie RN 1972 A controlled trial of antepartum glucocorticoid treatment for prevention of the respiratory distress syndrome in premature infants. Pediatrics 50:515-525

20. Lowry OH, Rosenbrough NJ, Farr AL, Randell RJ 1951 Protein measurement in folin-phenol reagent. $\mathrm{J}$ Biol Chem 193:265-275

21. Mashiach S, Barkai G, Sack J, Stern E, Brish M, Goldman B, Serr DM 1979 The effect of intra-amniotic thyroxine administration on fetal lung maturity in man. J Perinat Med 7:161-170

22. Miller TB Jr 1983 Altered regulation of cardiac glycogen metabolism in spontaneously diabetic rats. Am J Physiol 245 (Endocrinol Metab 8):E379E383

23. Neufeld N, Melmed S 1982 3,5 dimethyl $3^{\prime}$ isopropyl thyronine (DIMIT) treatment in diabetic pregnancy: glycogenetic effects on fetal tissues. Pediatr Res 16:1099 (abstr)

24. Olefsky JM 1981 Insulin resistance and insulin action: An in vitro and in vivo perspective. Lilly Lecture 1980 . Diabetes 30:148-162

25. Olefsky JM, Johnson J, Lui F, Jen P, Reaven GM 1975 The effects of acute and chronic dexamethasone administration on insulin binding to isolated rat hepatocytes and adipocytes. Metabolism 24:517-527

26. Pfleider G 1965 In: Bergmeyer H (ed) Methods of Enzymatic Analysis. Academic Press, New York, pp 59-62

27. Rockson SG, Homcy CJ, Quinn P, Manders WT, Haber E, Vatner SF 1980 Cellular mechanisms of unpaired adrenergic responsiveness in neonatal dogs. 
J Clin Invest 67:319-327

28. Sauerheber RD, Kuhn CE, Hyslop PA 1984 Membrane structural/functional properties of adipocytes from normal and streptozotocin-diabetic rats. Diabetes 33:258-264

29. Scatchard G 1947 The attraction of proteins for small molecules and ions Ann NY Acad Sci 51:660-672

30. Simmons MA, Jones MD, Battaglia FC, et al 1978 Insulin effect on fetal glucose utilization. Pediatr Res 12:90-92

31. Sinha MK, Miller JD, Ganguli S, Sperling MA 1983 Differential maturation of insulin sensitivity for glucose and amino acid metabolism in rat hepatocytes. Pediatr Res 335:17 (abstr)

32. Sperling MA 1978 In: Stave U (ed) Insulin and Glucagon in Perinatal Physiology. Plenum Press, New York, pp 813-829

33. Sperling MA, Delamater PV, Phelps D, Fiser RH, Oh W, Fisher DA 1974 Spontaneous and amino acid stimulated glucagon secretion in the immediate postnatal period. Relation to glucose and insulin. J Clin Invest 53:11591166

34. Sterman BM, Ganguli S, Devaskar S, Sperling MA 1983 Hypothyroidism and glucocorticoids modulate the development of hepatic insulin receptors. Pediatr Res 17:111-116

35. Thakur AK, Jaffe ML, Rodbard D 1980 Graphical analysis of ligand binding systems: evaluation by Monte Carlo Studies. Anal Biochem 107:279-295

36. Volpe JJ 1981 Hypoxic-ischemic encephalopathy: basic aspects and fetal assessment. In: Neurology of Newborn. WB Saunders Co, Philadelphia, M PCP XXII, pp 141-179

37. Whitsett JA, Darovec-Beckerman C, Adams K, Pollinger J, Needleman $H$ 1980 Thyroid dependent maturation of $\beta$-adrenergic receptor in the rat lung. Biochem Biophys Res Commun 97:913-917

38. Zamenof S, Burszytn H 1964 The determination of deoxyribonucleic acid and of cell number in brain. J Neurochem 11:505-510

\title{
Urinary Excretion of an Isomer of Bilirubin during Phototherapy
}

\author{
ISABELLA KNOX, JOHN F. ENNEVER, AND WILLIAM T. SPECK \\ Department of Pediatrics, Rainbow Babies and Childrens Hospital, Case Western Reserve University School of \\ Medicine, Cleveland, Ohio 44106
}

\begin{abstract}
Lumirubin, a water-soluble photoproduct of bilirubin formed in vivo during phototherapy, is excreted in the urine. In premature infants with little or no bilirubin conjugating activity, lumirubin is the principal yellow pigment found in the urine during phototherapy. The clearance rate of lumirubin in nine premature infants varied from 0.05 to $0.65 \mathrm{ml} / \mathrm{min}$ and increased with postconceptional age in parallel with increased creatinine clearance rate. The amount of lumirubin excreted per $24 \mathrm{~h}$ was estimated to be from 0.2 to $9.4 \mathrm{mg}$ with a mean of $3.2 \mathrm{mg}$. The urinary excretion of lumirubin is a significant pathway for pigment elimination during phototherapy. (Pediatr Res 19: 198-201, 1985)
\end{abstract}

Visible light phototherapy has been used to treat neonatal hyperbilirubinemia for more than two decades $(1,2)$. Although precise data are not available, it has been estimated that between 2 and $5 \%$ of all newborn infants are treated with phototherapy (3). Despite this widespread use over a number of years, the mechanism by which phototherapy lowers serum bilirubin in vivo is not known. The purpose of this study was to determine whether urinary excretion is an important pathway for the elimination of bilirubin photoproducts.

Bilirubin, a metabolic product of heme degradation (4), is a highly lipophilic molecule (5); prior to excretion, bilirubin is made more water soluble by conjugation to glucuronic acid (6).

Received July 12, 1984; accepted October 3, 1984.

Address correspondence and requests for reprints to John F. Ennever, Ph.D. M.D., Department of Pediatrics, Rainbow Babies and Childrens Hospital, 2101 Adelbert Road, Cleveland, $\mathrm{OH} 44106$.

Supported by the U.S. Public Health Service through Grants CA-23692 and Research Career Development Award 1K0-0043 to W.T.S.
Because newborn infants are deficient in the enzyme(s) responsible for this conjugation reaction they frequently develop hyperbilirubinemia which is most often treated with phototherapy. During phototherapy, bilirubin undergoes two principal photochemical reactions, which yield products that are more polar than the native molecule $(7-10)$. The relative importance of these two reactions to the therapeutic response seen with phototherapy depends on both the rates of formation and the rates of excretion of the photoproducts.

The two principal photoproducts are $4 Z, 15 E-b i l i r u b i n$, a configurational isomer of the native 4Z,15Z-bilirubin (9), and lumirubin, a structural isomer which contains a seven-member ring (10) (Fig. 1). The relative rates of the two reactions are known from in vitro studies (9-11) and appear to be similar in vivo (12). The faster reaction is the configurational isomerization which is freely reversible. The formation of lumirubin occurs more slowly (11) but is essentially irreversible. Typically during phototherapy, 2 to $6 \%$ of the total bilirubin is present as lumirubin whereas 15 to $20 \%$ is present as the configurational isomer (12). A third type of reaction, the photooxidation of bilirubin to mono and dipyrroles (13) occurs at a much lower rate than either isomerization reaction (11) and is not thought to be a quantitatively important pathway for bilirubin elimination.

The decline in serum bilirubin during phototherapy requires not only formation of these bilirubin isomers but also their elimination. The principal route of photoproduct elimination is thought to be through the bile. Onishi et al. (8) have reported finding a bilirubin photoproduct, which they called "unknown pigment," in the bile and urine of infants treated with phototherapy. We have used a high pressure liquid chromatographic method to quantitate the urinary excretion of bilirubin isomers in nine preterm infants. We have identified the photoproduct in the urine as the configurational isomer of bilirubin, lumirubin. We have determined the rate of urinary excretion of lumirubin 